\title{
OPTIMIZATION OF INSTRUCTIONAL DEMONSTRATION TECHNIQUE TO IMPROVE TEACHERS'SKILL TEACHING WITH COOPERATIVE MODEL AT SMP MAARIF 5 METRO \\ ACADEMIC YEAR 2015/2016 \\ By \\ Muizzuddin \\ A Junior High School Supervisor of Metro City Lampung Email:drsmuizuddin@gmail.com
}

\begin{abstract}
At Junior High School (known as SMP) Maarif 5 Metro, routine supervision conducted by researcher as the supervisor found that most of the teachers still carried out instructional process in a traditional way. Teachers practiced their class without making their own lesson plan. They had tendency to apply existed print out lesson plan and failed to do cooperative instruction. The instructional process was categorized low quality and the teachers'performance in teaching were not focusing on students centered with optimum cooperative model. The aim of the research were to improve supervisor's ability in implementing academic supervision throughdemonstrationand to improve teachers'performance of SMP Maarif 5 Metro practicing cooperative model in their classes in Academic Year 2015/2016.Subjects of the research were the teachers of SMP Maarif 5 Metro, there were 12 teachers involved, and divided into three groups. The object of the research was teachers'performance in applying various cooperative instructional methods. At the same time, the supervisor ability in implementing group supervision technique through demonstration technique. The research was done at odd semester, for four months, from July to September 2015. The researcher concluded that teachers'performance in implementing cooperative model at SMP Maarif 5 Metro could be improved through the optimization of demonstration technique. Findings support the conclusion are $58 \%$ sufficient category at cycle I reduced to $31 \%$ at cycle II. Good category $69 \%$ at cycle I increased to $83 \%$ at cycle II. Very good category increased to $17 \%$. Some respondens, who previously disagreed, agreed that supervisors'performance was very good. It was so because good predicate became $58 \%$ and very good predicate became $42 \%$ from $0 \%$.
\end{abstract}

Key Words : Supervision, Demonstration, Cooperative

\section{A. Introduction}

The presence of good quality

instruction at school is a must for teachers.

Yet, it seems that the expected situation

failed to meet by the teachers. The teachers

are often lack of creativity to implement

newer instruction model or techinque. Most

teacher can not empower strategy, art and

style of advanced teaching. At Junior High

School (known as SMP) Maarif Metro,

routine supervision conducted by researcher

as the supervisor found that most of the teachers still carried out instructional

process in a traditional way. Teachers

practiced their class without making their

own lesson plan. They had tendency to

apply existed print out lesson plan and

failed to do cooperative instruction. Most

teachers do pure preaching, lack of

variation and media, The instructional

process was categorized low quality and the

teachers'performance in teaching were not

focusing on students centered with

cooperative model optimally which might 
train independency and responsibility of the students.

The condition can be justified by seeing the supervision result conducted by research earlier from 12 teachers of SMP Maarif Metro. Averagely, teachers were not able to implement students learning centered cooperatively. The teachers practiced plain instruction in their classes.

The insruction conducted were merely preaching without any variation and less effective, without grouping the student to promote cooperative learning.

Instructional process at SMP Maarif 5 Metro was still classified as low quality and the teachers'performance was strongly teacher centered. As evidents, most of the students were at low achievement and failed to meet both the school and parents expectation.As a part of supervision process, the supervisor also observed the activity of the principal. It was clear that the principal was lack of ways to perform his supervision task. In fact, the principal supervision was only routine check without variation of approach and was not done seriously to do with cooperative model.

The condition leads the supervisor to push all teachers doing student centered learning on the basis of cooperative model, as it is an accordance with the regulation of process standard (Permendiknas, No 41 tahun
2007). The regulation is a guidance which has to embody in instructional process as teachers play the an important role in their classes. When teachers practice their teaching with the implementation of cooperative centered, it can be assumed that the instruction process will likely to be satisfactory, and due in time will improve students'learning achievement.

The teachers'ability and their skill in compiling lesson plan of well organized cooperative instruction will promote effective learning to meet the curriculum target in accordance with the competency standard and basic competency. Besides being creative of grouping the students within small size during instructional process, the condition will grow learning motivation and students'spirit to know more. Students'creativity will keep blooming and their retention remains high from meaningfull instruction. Colorful learning activity will increase every day. The teachers'ability and their skill to embody cooperative learning will go along with school vision and mission previously formulated.

The supervision has an intention to change instructional process done by teachers to be better. It is abridged by certain instrument related to their 
instruction. The target is to change teachers'behaviour be more creative during their class and attract more attention and interest from the students. The academic supervision through instructional demonstration shall motivate teachers and lead them to embrace the sense of instruction agents who get along with the regulation. The supervisor needs to carefully plan the supervision program through instruction demonstration and ceaselessly trying to improve teachers'performance with order and manner.

The objectives of the research were to improve supervisor's performance in implementing academic supervision through instruction method for the teachers, and to improve teachers'performance of SMP Maarif 5 Metro in implementing cooperative model instruction in Academic Year 2015/2016.

\section{B. Framework Thinking}

Supervision at individual from a school supervisor is a model of mentoring which directly hits the target, that is to know the level of teacher's ability in the classroom practice. In this type of supervision technique, the supervisor acts himself as peer teacher and directly involve interpersonally to create lesson plan.
Teachers ought to fear not of supervisor any longer, they can freely bring up their ideas and feel comfortable to when they do. The supervisor actively demonstrate and simulate cooperative instruction. Teachers may feel being noticed and assisted, comfortable and deeply touched to do their classroom practice. Eventually, from such internalization, their task performance shall be better to promote better learning process and improve students'achievement.

Believe in the notion, it is presumably that academic supervision through instruction demonstration, done by grouping in the first and second cycle, teachers were driven to implement cooperative instruction will improve students'achievement. Teachers will likely initiate seriously that the students form their small group, so that the students will be enthusiastically follow the class. The evaluation shall reach higher score, not only the score but the creation of true achievement expected by the society as well.

\section{Research Method}

Steps done in the research was cyclical. School action research is a treatment research consist of step 1) planning, 2) acting, 3) observing, 4) reflecting (Arikunto et all, 2006). The plan 
was initiated by having some meeting with the teachers of SMP Maarif 5 Metro. At the meeting, some example of cooperative instruction implementations were discussed, and the file were given to all teachers. Next activity should be on the basis of reflection from previous meeting.

\section{Subject, Object, Location, and Time of}

\section{The Research}

Subjects of the research were the teachers of SMP Maarif 5 Metro as many 12 teachers and divided into three groups in Academic Year 2015/2016. The research objects were teachers'performance in practicing variation cooperative instruction in their classrooms. At the same time, the supervisor's performance in implementing group supervision technique with subtechnique of instruction demonstration. The research was done at SMP Maarif 5 Metro located at Street Mr. Gele Harun, Number 22 Kauman, PO. BOX. 234, Telephone. 0725-7852032. Time was adjusted with supervision schedule at SMP Maarif 5 Metro. It was done in odd semeste, as long as four months from July to September 2015.

\section{Conceptual and Operational Definition}

a. Conceptual Definition

\section{Instruction Demonstration Technique}

The implementation of demonstration technique in the supervision was meant to expose the teachers how to carry out an instructional method. Through this way, it is expected that the teachers will master various cooperative technique to instruct the students in their classrooms practice.

\section{b. Teachers'performance in}

\section{Implementing Cooperative Model}

There are 13 models of cooperative instruction, they are; 1) Two Stay Two Stray, 2) Group Moving Around; 3) Make A Match; 4) Changing Match; 5) Co-Op Co-Op; 6) Learning Together LT; 7) Team Product; 8) Inside Outside Circle; 9) Spontaneous Group Discussion (SGD);10) Listening Team; 11) Snowball Throwing;

12) Bamboo dance; 13) Structured Numbered Heads;

\section{Operational Definition}

\section{a. Instruction Demonstration Technique}

Supervision activity by involving teachers of SMP Maarif 5 Metro to demonstrate instruction using various cooperative model interchangably in their classroom after they were exposed to the implementation of each technique.

\section{b. Teachers'performance in}

\section{Implementing Cooperative Model}


Teachers'performance in implementing cooperative instruction covers sintax of each model, flexibility, mastery of each cooperative model, class managemnet to minimize weaknesses of coopeative model and to optimize the strength.

\section{Treatment Duration and Performance} Indicator of the Research

Success indicator is achieved when supervisor performance in implementing demonstration technique reaches good predicate as many as $75 \%$ of the descriptor. If teachers'performance in implementing cooperative technique reaches good predicate as many as $75 \%$ of the descriptor, it means the success indicator is achieved and the treatment must stop.

\section{E. Data Analysis Technique}

\section{1) Data Validity and Realibilty}

In order to maintain the validity of data previously taken, it is necessary to validate the data through: 1) obervation consistancy which means "Searching consistantly, interpreting with various ways in relation with analysis process both constant or tentative"; 2) Member check (Moleong, 1989) which means what result comes up from supervisor observation on instructional process must be compromised to peer through a reflection at the end of the instructional process. 3) Tringulation is a technique of data validity check by taking advantage of something outside the data taken, as a comparison. Triangulation can also be done through understanding test of the researcher to informen (Bungin, 2003). In order to avoid the difference of understanding, triangulation is carried out by checking the informen's understanding.; 4) Peer check means that examination is carried out by assembling peers who master general knowledge related to the object. By doing so, together, every one can review perception, point of view, and analysis on the object; 5) consulting the findings to senior as an expert opinion.

\section{2) Data Presentationn}

Quantitative data is analized by calculating the frequency. For each variable, both optimization demonstration technique or teachers'performance in implementing cooperative instruction model must be categorized to some predicates as follows a) The amount of item $\mathrm{x}$ highest score $=$ amount of the score; $\mathrm{b}$ ) Amount of the score/4 categories =interval of category class; c) The frequency of each class used as criteria of achievement success indicators of the research. How many frequency occurs are can be presented on histogram. 


\section{F. Result}

\section{Optimization of Instruction}

\section{Demonstration Technique}

The result of Optimization of

Instruction Demonstration Technique in the implementation can be observed on the picture.

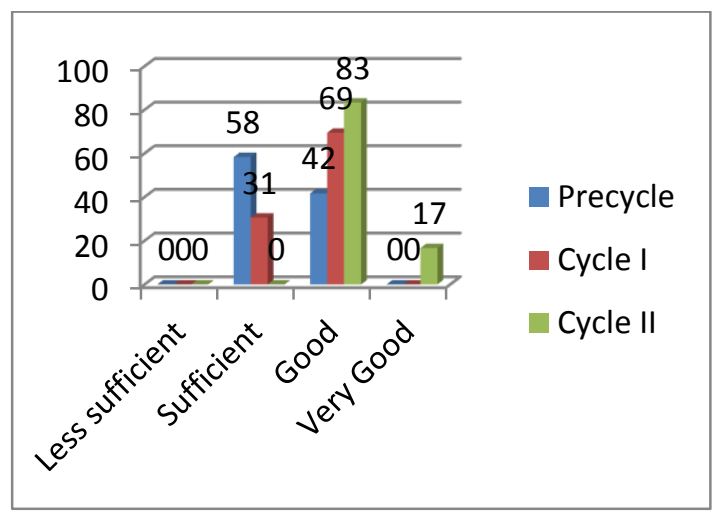

Figure 1. The Implementation of Instruction Demonstration Technique

The steps of optimizing supervisor role to instruct the teachers in implementing cooperative model was scored by each teacher as respondens. There are five aspects; 1) creating harmony relationship, 2) needs analysis, 3) developing strategy and media, 4) evaluating, 5) revision. Figure 1 tell us there is no less sufficient predicate because the the steps are in sufficient and good category. Sufficient category $58 \%$ at precycle and then goes down to $31 \%$ at cycle I. Good category $42 \%$ at precycle and increases to $69 \%$ at cycle I. The decrease at precycle to cycle I due to the shift of predicate. It indicates the improvement of supervisors'performance in implementing cooperative model. In cycle II, the predicate of the implementation steps is getting much better. Interaction for few weeks with the teachers earlier has abridged the psycological distance. Communication becomes more comfortable. Sufficient predicate from $58 \%$ becomes $31 \%$ in cycle II. Good predicate from $69 \%$ becomes $83 \%$. Very good predicate from $0 \%$ becomes $17 \%$. Some teachers who admit very good performance for the supervisor are those who gave low score.

\section{Teachers'performance in Cooperative}

\section{Model Instruction}

The measurement of teachers in cooperative model instruction used two instruments of observation. The observation instruments are the accumulation of all aspects support the teachers"'performance, meanwhile, the adaptabilty of sintax was intended to take a close look which step of each cooperative model whether they missed the steps during implementation or the steps need to be amended.

\section{1) Teacher's Performance}

Teacher's performance in implementing cooperative technique consist of 5 aspects: 1) mastered model;2) sintax; 3) class management; 4) strength optimization; 5) weakness minimization. The result can be seen as follows: 


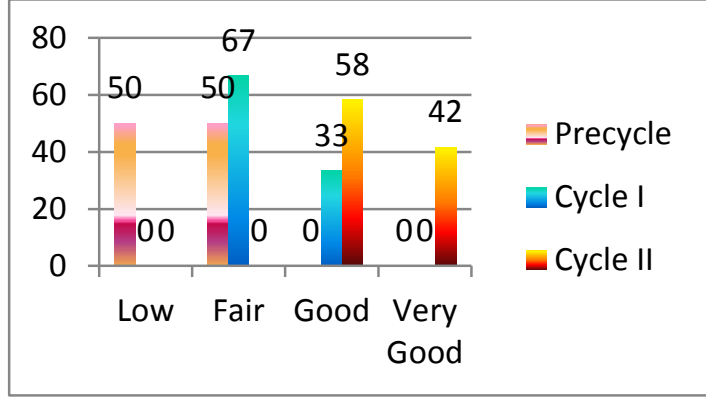

Figure 2Teacher's performance in Implementing Cooperative Technique

In the beggining, as many $50 \%$ of the teachers had low performance, meanwhile another $50 \%$ had fair performance. When cycle I treat done, no more low performance existed, the teachers shifted to fair predicate as many $67 \%$ and other turned into $33 \%$ good predicate. The improvement went along with supervisor'performance although none of them reached very good predicate. At cycle II, good category reached $58 \%$ from $33 \%$ at cycle I. And then, very good predicate which was $0 \%$ at cycle turned into $42 \%$ at cycle II. There are two categories at cycle II, good and very good, which accumulate to $100 \%$.

\section{2) The Consistency of Cooperative Sintax}

There are 72 items of sintax classified into 13 cooperative model. The result can be found below here.

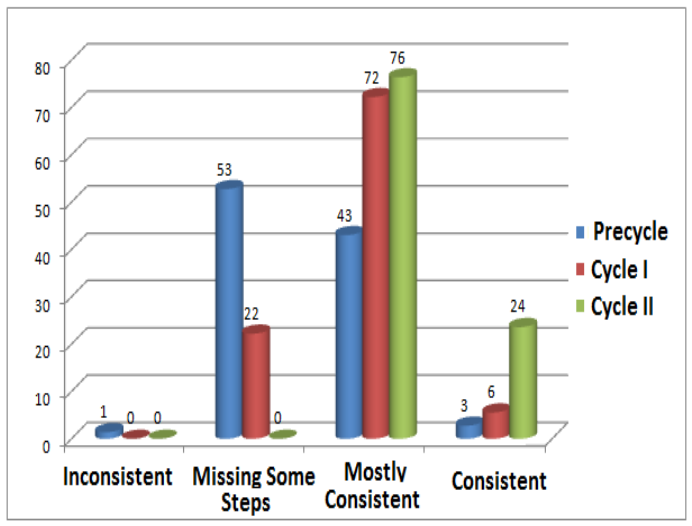

Figure 3 Consistency of Cooperative Sintax Clearly seen at precycle, Inconsistent was only $1 \%$, Missing some steps $53 \%$, and Mostly consistent $43 \%$, even Consistent predicate reached $3 \%$. The condition is understandable as pre performance of SMP Maarif 5 Metro. At cycle I, Inconsistent decreased to $22 \%$, Mostly consistent increased to $72 \%$, and Consistent increased to $6 \%$. At cycle II. The consistency just gets better. Mostly consistent reached 76\%, consistent reached $24 \%$. The amount of mostly consistent and consistent predicate is now $100 \%$.

\section{G. Discussion}

\section{Optimization of Instruction}

\section{Demonstration Technique}

The event was initiated by assembling all teachers of SMP Maarif 5 Metro through invitation. When ceremonial done, the teachers were then exposed to many samples of instruction cooperative model using LCD projector. Every sample was discussed within small group of the 
teachers. The supervisor distributed the sintax transcript of 13 cooperative model. The discussion let the teachers examine carefully to the transcripts and rectify them when necessary. Every group of teacher was then given a chance to demonstrate one cooperative model while others observe the demonstration. Review done after the session.

The meeting lasted for 5 hours from 08.00 to 14.30 . During the meeting, 4 cooperative models were demonstrated. The next discussion was the schedule of the implementation in their classes. It came to an agreement that the implementation a week later. First group 2 days, Monday and Tueday. Second group two days,

Wednesday and Thursday. Third group two days, Friday and Saturday. Review done at the same day right after the implementation. Observers were their peers.

Implementing academic supervision steps were not easy. It was so because there were many adjustment needed to make during the process at SMP Maarif 5 Metro. Due to the concept of modern supervision,"Supervision is assistance in the devolepment of a better teaching learning situation", (Kimball, 1967). The concept signify that supervision service covers all instruction process (goal, material, technique, method, teacher, student, and environment). The learning environment mostly need urgent attention from supervision process. Due in time, the adjustments passed quite well. The supervisor were able to build harmony relationship among teachers to drive them achieving the goal of mentoring.

Being open to each other when having discussion on shortcomings after the implementation is healthy way to overcome the problem found. Hereby, the supervisor behaved professionally during the process of mentoring. Showing professionality with care is a must for a supervisor to conduct his duty. This goes relevantly to "Supervisi adalah proses bimbingan profesional untuk meningkatkan derajat profesionalitas guru bagi peningkatan mutu proses pendidikan dan pembelajaran, khususnya prestasi belajar siswa",(Danim dan Suparno, 2009). Conducting supervision to teachers has changed their behaviour, the way they delivered their teaching practice became more effective to improve learning achievement and eventually, education quality.

More over, need analysis insists on applying various strategy and media to reach academic supervision goals. Need analysis requires cold hand to collect all information necesssary expected. In general, the academic supervision goal is to 
facilitate teachers in developing their performance for better teaching practice in their classroom. The supervision technique basically classified into two groups, they are individual technique and group technique, (Gwynn, 1961). Which is why a supervisor needs to be creative, by implementing instruction demonstration technique among other thing, as an effort to help the teacher build and develop their potential so that the instruction process in their classroom are acceptable to what required in the regulation. A supervisor can both use individual and group mentoring, the choice depends on teachers'character, (Syaiful,2010).Demonstration techique motivate the teacher to adopt and adapt the sintax of cooperative model and hence, they build their stronger self confidence to apply the methods in their classroom due to their prevoius experience when implementing the various model under supervision and observation of their peer.

\section{Teachers'performance in Cooperative}

\section{Model Instruction}

Repetation and time interval in a day for each cooperative model gave more time for teachers to practice the sintax which will be implemented the next day. Some difficulties encountered were support unsure related to the model such as cards, worksheets, material copy which will be used in the discussion. How big the difficulty is depend on each teacher capacity. During implementation of cooperative model, peer of each group played as observer.

Teachers are central figure at school, they have main role to determine both quantity and quality of instruction in their classrooms. Teachers must consider carefull plan to organize learning occurance of each student. To do so, teachers must make change toward better way of class management, instruction strategy and method, approach, attitude and character during instructional process. Teachers act as managers during classroom practice, they facilitate students to created effective learning atmosphere. When teachers are effective, they will likely effect quality improvement both process and output.

Teaching is an effort of organizing environment to create learning condition for the students, (Hamalik, 2009). Based on this notion, teaching process accentuates on other unsure, they are: students, environment and learning process. Which is why it is extremely important for teachers to master pedagogy well in order to be able to run and manage effective instructional event to promote better behaviour of the students. One of aspects in pedagogy 
competency is mastering cooperative model.

The apply of one model in paralel scheduled classroom in the same day made the teachers easier to master cooperative sintax. The repetation becomes training media and habituation, even to find the meaning behind the sintax. The training accentuated on competency development individually, mainly focus on students'potential. The traning can be done on a group students, but the focus remains on individual development. This method can be achieved under guidance, without guidance and supervision. Especially since the development may take place in their classrooms.

The chance of becoming an observer when peers were implementing cooperative instruction was also a media of teaching himself, identifying or even anticipating the possibility of making mistake when an observer turned to be a doer of the cooperatice implementation. Being an oberver also proven to be a training media to comprehend deeper on the various sintax of each cooperative model. This goes along with an opinion that "Latihan siap dimaksudkan untuk memperoleh ketangkasan atau keterampilan latihan terhadap apa yang dipelajari, karena hanya dengan melakukan secara praktis suatu pengetahuan dapat disempurnakan," (Ramayulis, 2005). Implementing and observing and then reimplementing became an effective media to promote teachers in mastering the variation of cooperative instruction.

The improvement of each sintax item from a various cooperative instruction model was a result of well cooperation between teachers and the supervisor. How the idea and notion accomodated toward the implementation, and proper observation delivered by the supervisor made all supervision worked out. It becomes a proof that demonstration method in supervision is really beneficial. Since the improvement achieved the success indicator, the treatment stopped.

\section{H. Conclusion and Suggestion}

\section{Conclusion}

Theresearcher was finally able to conclude that teacher performance in implementing cooperative instruction model at SMP Maarif 5 Metro could be improved through the optimization of instruction demonstration method. Findings support the conclusion are as follows:

1) In cycle II, the predicate of the implementation steps is getting much better. Interaction for few weeks with the teachers earlier has abridged the psycological distance. Communication 
becomes more comfortable. Sufficient predicate from $58 \%$ becomes $31 \%$ in cycle II. Good predicate from $69 \%$ becomes $83 \%$. Very good predicate from $0 \%$ becomes $17 \%$. Some teachers who admit very good performance for the supervisor are those who gave low score.

2) At cycle II, good category reached 58\% from $33 \%$ at cycle I. And then, very good predicate which was $0 \%$ at cycle turned into $42 \%$ at cycle II. There are two categories at cycle II, good and very good, which accumulate to $100 \%$.

3) At cycle II. The consistency just gets better. Mostly consistent reached $76 \%$, consistent reached $24 \%$. The amount of mostly consistent and consistent predicate is now $100 \%$.

\section{Suggestion}

Some suggestions deserve to present as follows

1) Academic supervision needs to be intensified. Earlier supervision must visit classroom practice to see how well the teachers implement various strategy during instructional process.

2) The findings shall be the basis of consideration in sceduling academic supervision as part of coordination with the teachers.
3) Directive approach is always proper to apply in the first meeting, what follows later is instruction demonstration method.

4) When first cycle treatment done, the implementation of cooperative model shall apply on paralel classroom, a time interval for rehearse follows next.

5) At second cycle, treatment with instruction demonstration method followed by training method.

6) Peer empowerment as obersever when teachers implement their cooperative model is a reciprocal beneficial way. 


\section{References}

Arikunto, Suharsimi; Suhardjono dan Supardi. (2006). Penelitian Tindakan Kelas. Jakarta: Bumi Aksara

Bungin, Burhan. (2003). Analisis Data Penelitian Kualitatif: Pemahaman Filosofis dan Metodologis keArah Penguasaan Model Aplikasi. Jakarta: Rajagrafindo Persada..

Danim Sudarwan dan Suparno, (2009). Manajemen dan Kepemimpinan Transformasional

Kekepalasekolahan, Jakarta : Rineka Cipta..

H. Syaiful. (2010). Supervisi Pembelajaran Dalam Profesi Pendidikan, Bandung: Alfabeta
Hamalik Oemar. (2009). Proses belajar Mengajar, Jakarta: PT Bumi Aksara,.

J. M.Gwynn, (1961). Theory and Practice of Supervision. New York: Dodd, Mead and Company

Kimball Wiles. (1967). Supervision for Better Schools. Englewood Cliffs, N.J. Prentice-Hall

Moleong, Lexy. J. (1989).Metode Penelitian Kualitatif. Bandung: Remaja Rosdakarya.

Permendiknas No 41 tahun 2007, Tentang Standar Proses

Ramayulis, (2005). Metodologi Pendidikan Agama Islam, Jakarta : Kalam Mulia. 